\author{
Milena Kolarević \\ Energoprojekt - Hidroinženjering \\ Ljubodrag Savić \\ Professor \\ University of Belgrade \\ Faculty of Civil Engineering \\ Radomir Kapor \\ Professor \\ University of Belgrade \\ Faculty of Civil Engineering \\ Nikola Mladenović \\ Professor \\ University of Belgrade \\ Faculty of Mechanical Engineering
}

\section{Supercritical Flow in Circular Pipe Bends}

In this paper a complex flow pattern occurring in a closed conduit bend with supercritical flow is analyzed. The research was done by a scale (physical hydraulic) model, and a numerical model developed in Ansys (Fluent) program surrounding. This article compares the results obtained by numerical and physical (scale) models, providing comments and recommendations for their application. Based on these results, simple empirical relationships were developed, describing the effects of the bend deflection angle and approach flow conditions (non dimensional depth and the Froude number upstream from the bend) on the considered flow.

Keywords: supercritical flow, horizontal bend, closed conduit, scale model, numerical model.

\section{INTRODUCTION}

Supercritical flow in a circular conduit with the horizontal-plane direction change causes abrupt depth and velocity perturbations, spreading downstream in the form of standing waves (fig. 1.). At the beginning of the bend, a positive wave is developed along the outer wall of the bend (concave wall), and a negative wave along the inner wall (convex wall).

Free surface flow in a circular bend may convert into helicoidall flow, or into pressurized (choking) flow. The deflection angle and the bend curvature are considered to be the most influential geometrical factors in this type of flow. In this research, the effect of deflection angle is examined, while the bend curvature effect will be the topic of a following study. This article compares the results obtained by hydraulic scale (physical) and numerical model, providing comments and recommendations for their application.

The hydraulic scale model was built at the laboratory of Faculty of Civil Engineering in Belgrade. Hydraulic features of the bend flow were examined by the scale model investigations, in terms of the deflection angle, and the approach flow conditions, described through: non dimensional depth, $h_{0} / D$, and Froude number, $F r_{0}=v / \sqrt{g h}$ (fig. 1). Based on the results of the scale model investigations, simple empirical relationships were developed, describing influence of the before mentioned parameters. Also, the results from the scale model were used for calibration of the numerical model.

Gisonni and Hager [1] analyzed free surface bend flow in a bottom outlet of the circular cross section. The hydraulic experiments were conducted for the bend curvature of $D / R=1 / 3$, with the deflection angle of $45^{\circ}$. For all experiments, a non dimensional approach depth was constant, $h_{0} / D=0,6$, while approach Froude numbers varied between $1,4-4,2$. The authors [1] proposed the threshold condition for establishing of

Received: September 2013, Accepted: December 2013

Correspondence to: Milena Kolarević

Energoprojekt-Hidroinženjering,

Bul. Mihaila Pupina 12, 11070 Belgrade, Serbia

E-mail: milenakolarevic@yahoo.com

doi:10.5937/fmet1402128K

(C) Faculty of Mechanical Engineering, Belgrade. All rights reserved helicoidall flow, using choking number, $C$, defined as a product of a non dimensional approach depth and Froude number.

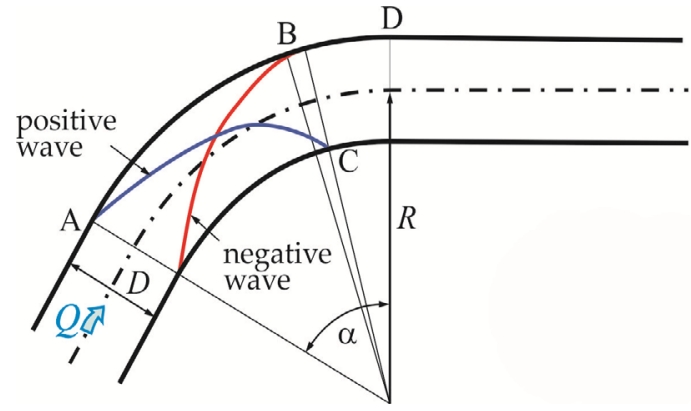

a) plan

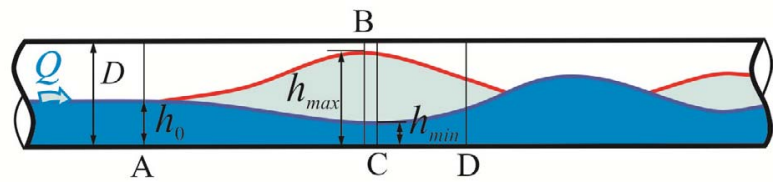

b) longitudinal section

Figure 1. Propagation of positive and negative waves along the conduit

\section{HYDRAULIC SCALE MODEL INVESTIGATIONS}

Experimental installation consists of (fig. 2.):

- The upstream reservoir, providing controlled inflow to the conduit

- The conduit (inner diameter $D=15 \mathrm{~cm}$ ) with horizontal bend, and upstream and downstream straight reaches

The conduit is horizontal, and the flow is steady. The length of the inlet-transition reach, from squared to circular cross-section, is $45 \mathrm{~cm}(3 D)$. The length of the straight upstream reach is $245 \mathrm{~cm}$, while the downstream reach is $150 \mathrm{~cm}$. The inlet is hydraulically shaped to provide minimal disturbances in an approach flow towards the bend. The approach flow conditions are set by changing the gate opening and the water depth in the reservoir. Water flow is measured upstream from the reservoir.

The hydraulic experiments were conducted for the bend curvature of $D / R=1 / 3$ and the deflection angles of $15^{\circ}, 30^{\circ}, 45^{\circ}, 60^{\circ}, 75^{\circ}$ and $90^{\circ}$. 


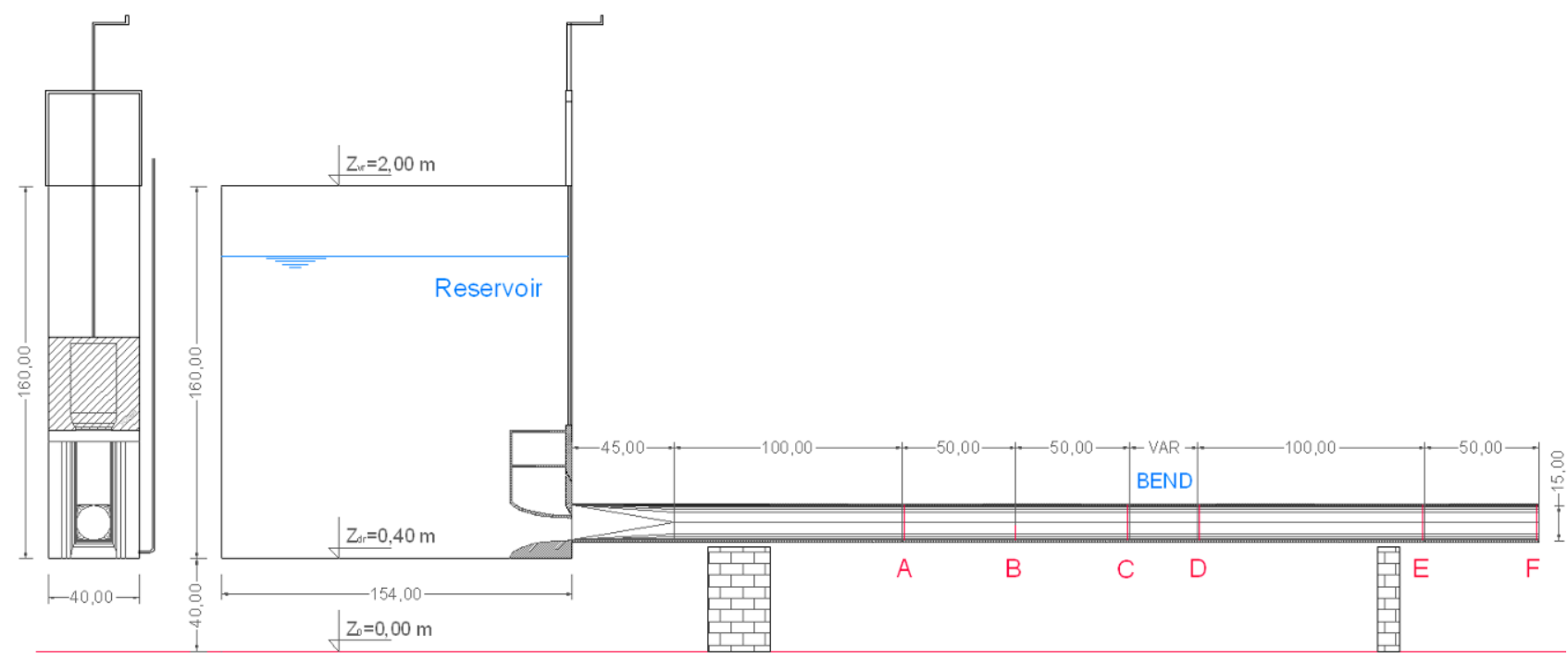

Figure 2. Longitudinal section of experimental installation

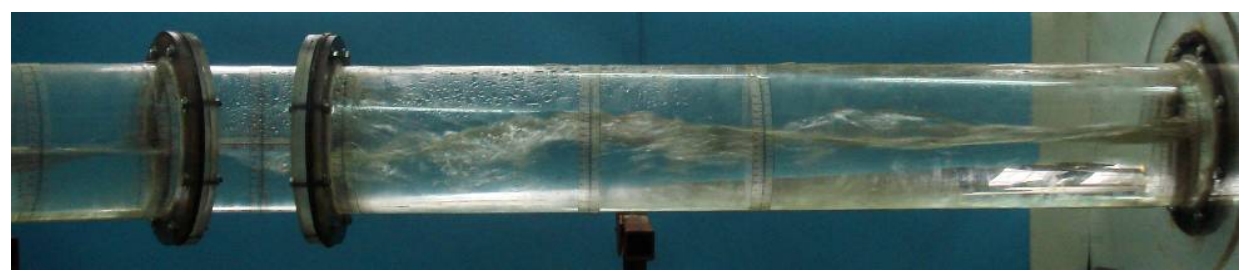

a) Flow without turning the jet - stratified flow

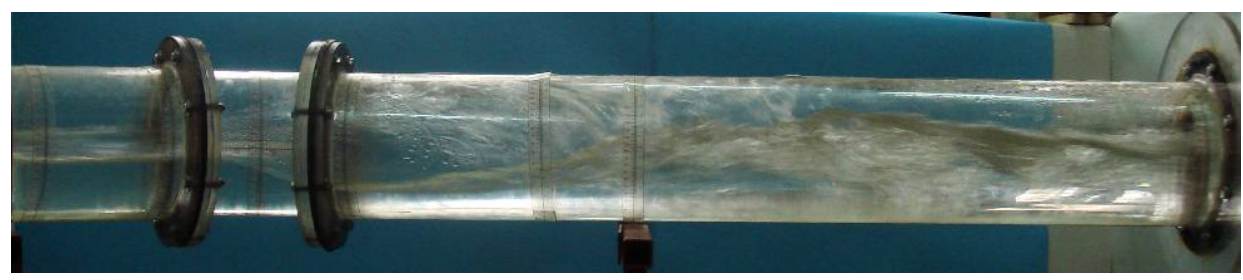

b) Flow with partially turning

of the jet

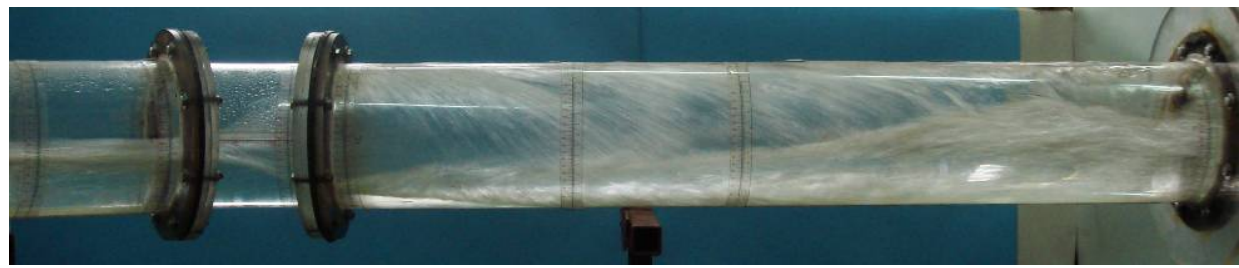

c) Helicoidal flow without choking

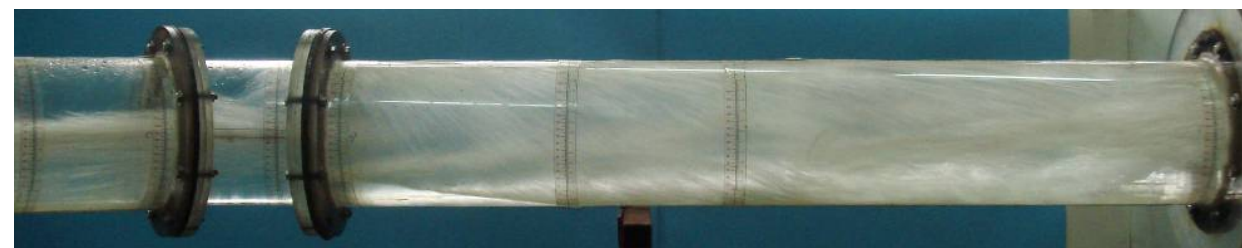

d) Helicoidal flow with choking - chocking flow

Figure 3. Characteristic flow patterns in circular conduit bend

\subsection{Analyses of experimental investigations}

The Flow in the hydraulic scale model is classified in one of the four categories-types (Fig. 3.)

1) Flow without turning of the jet around the conduit axes - stratified flow,

2) Transition flow, with partiall turning of the jet,

3) Helicoidal flow, with complete turning of the flow around the conduit axes, without choking,

4) Helicoidal flow with choking - choking flow.

This research included 182 experiments on the hydraulic scale model. Non dimensional approach depth, $h_{0} / D$, varied between $0,23 \div 0,84$, while the range of approach Froude numbers was $F r_{0}=v / \sqrt{g h}=1,5 \div 4,5$. For each setup, the threshold condition for establishing of helicoidall flow and choking flow were determined.

\section{THE INFLUENCE OF THE DEFLECTION ANGLE ON THE TYPE OF FLOW}

Figure 4 shows the limit between stratified and helicoidall flow, depending on $h_{0} / D$ and $F r_{0}$, for the considered deflection angles, and for the bend curvature of $D / R=1 / 3$. In the table within the figure, empirical 
relationships, defining the curves for angles of $15^{\circ}$ and $30^{\circ}$ are presented, while the single relationship is valid for angles of $45^{\circ}, 60^{\circ}, 75^{\circ}$ and $90^{\circ}$. Also is shown the empirical relationship for angle of $45^{\circ}$, according to [1]. All the curves proposed by the authors are above the curve from [1], suggesting that this curve is on the safe side. One can observe that the value of the deflection angle has an insignificant influence on the transition to helicoidal flow for angles larger than $30^{\circ}$. Almost all analyzed cases for deflection angles between $45^{\circ} \div 90^{\circ}$ revealed that the jet turns around the bend contour in the first $40^{\circ}$. The longitudinal free-surface slope along the concave bend wall does not depend on the deflection angle, but only on the bend curvature and the approach velocity. Therefore, transition to helicoidal flow is the same for the range of deflection angles between $45^{\circ}$ and $90^{\circ}$. The experiments with the angle of $15^{\circ}$ demonstrate that, in almost all the cases with helicoidal flow, the jet turns within the downstream straight reach of the conduit (but not in the bend itself). The longitudinal free surface slope becomes mild when the jet leaves the bend. Hence, the jet turns around the conduit axis further downstream than for the larger deflection angles; or it does not turn at all.
In the region between the deflection angles of $15^{\circ}$ and $30^{\circ}$, there are scenarios with the linear flow for the smaller, and helicoidal flow for the larger angles. Such an example is presented at fig.5, for the scenarios with angles of $15^{\circ}$ and $30^{\circ}$, and for the same inflow conditions $\left(h_{0} / D=0,5 ; F r_{0}=3,04\right)$.

In general, for the scenario with a larger deflection angle, and for the same inflow conditions, larger flow perturbations issue in the reach downstream of the bend, comparing to the case of a smaller angle. Hence, even if the flow have not fully turned for the larger deflection angle, it is still much more susceptible to become helicoidal, than for the case of a smaller angle. At the figure 6 , such a case is presented for the milder inflow conditions $\left(h_{0} / D=0,46 ; F r_{0}=2,61\right)$ than in the case from fig. 5 .

Figure 7. shows the choking flow limit, as a function on $h_{0} / D$ and $F r_{0}$, for considered deflection angles, with $D / R=1 / 3$, together with the corresponding empirical relationships. Reduction of the deflection angle, shifts the limit of choking to higher value $h_{0} / D$ and $F r_{0}$. Therefore, under the same approach flow conditions, choking will occur for higher values of deflection angle.

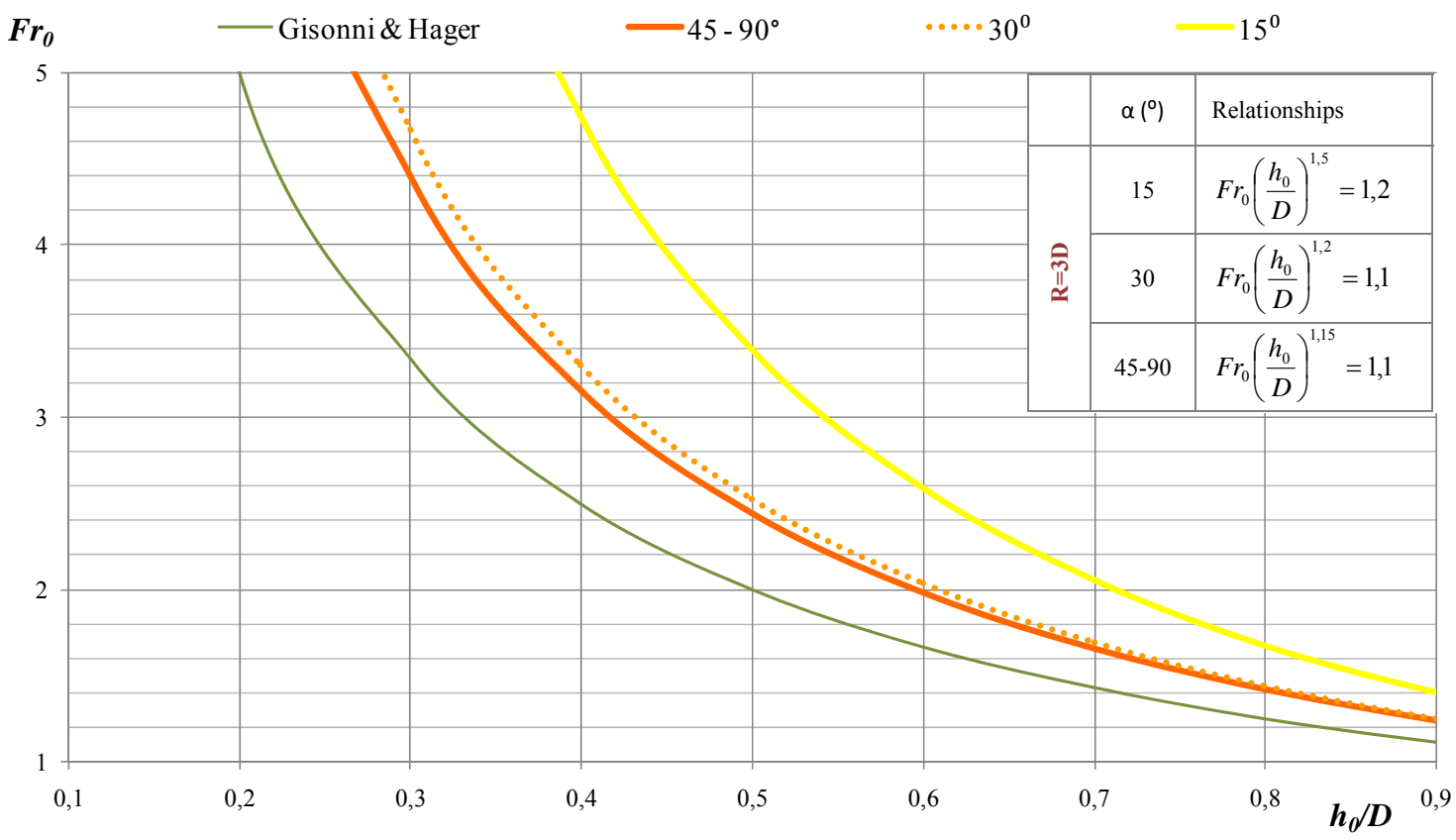

Figure 4. Limits between stratified and helicoidal flow for considered deflection angles and $D / R=1 / 3$

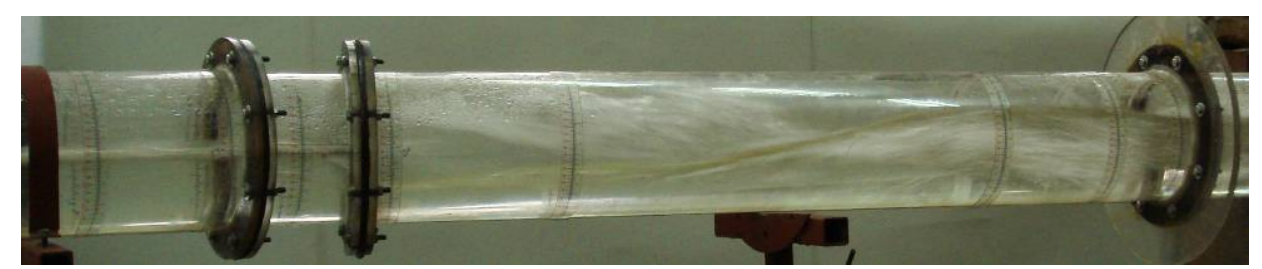

a) $\alpha=15^{\circ}$

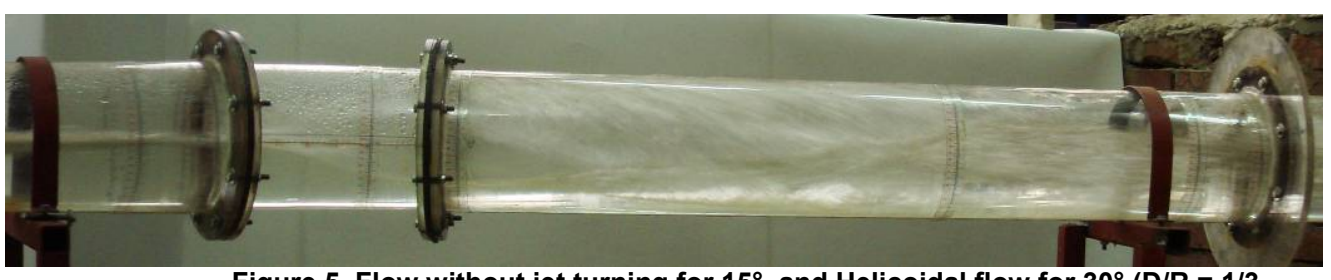

b) $\alpha=30^{\circ}$

Figure 5. Flow without jet turning for $15^{\circ}$, and Helicoidal flow for $30^{\circ}(D / R=1 / 3$ 


\section{NUMERICAL MODEL AND COMPARISON TO THE RESULTS BY THE SCALE MODEL}

The numerical model is based on partial differential equations for the spatial flow of water and air, NavierStokes equations. Conservative form of equations, referring to [2], [3], [4] and [5], can be written as follows:

$$
\frac{\partial}{\partial t}\left|\begin{array}{c}
\rho \\
\rho \mathbf{v} \\
\rho E
\end{array}\right|+\nabla\left|\begin{array}{c}
\rho \mathbf{v} \\
\rho \mathbf{v} \otimes \mathbf{v}+p \overline{\mathbf{I}}-\bar{\tau} \\
\overline{\bar{\tau}} \cdot \mathbf{v}-k \nabla T
\end{array}\right|=\left|\begin{array}{c}
0 \\
\rho \mathbf{\mathbf { f } _ { e }} \\
\rho \mathbf{f}_{e} \cdot \mathbf{v}+q_{H}
\end{array}\right|
$$

$$
\text { or, } \quad \frac{\partial \mathbf{U}}{\partial t}+\nabla \cdot \mathbf{F}_{T}=Q
$$

With the introduction of the total stress tensor $\overline{\bar{\sigma}}=-p \overline{\overline{\mathbf{I}}}+\bar{\tau}$, while $\overline{\overline{\mathbf{I}}}$ being unit tensor, the flux vector $\boldsymbol{F}_{T}$ can be written as:

$\mathbf{F}_{T}=\mathbf{F}-\mathbf{F}_{v}=\left|\begin{array}{c}\rho \mathbf{v} \\ \rho \mathbf{v} \otimes \mathbf{v}+p \overline{\mathbf{I}} \\ \rho \mathbf{v} H\end{array}\right|+\left|\begin{array}{c}0 \\ = \\ -\tau \\ =\overline{-\tau} \cdot \mathbf{v}-k \nabla T\end{array}\right|=\mathbf{v U}-\left|\begin{array}{c}0 \\ \bar{\sigma} \\ \bar{\sigma} \cdot \mathbf{v}-k \nabla T\end{array}\right|(3)$

Finally Navier-Stokes equations are:

$$
\frac{\partial \mathbf{U}}{\partial t}+\nabla \cdot\left(\mathbf{F}-\mathbf{F}_{v}\right)=Q
$$

Turbulence model for the analysis of the viscous effects of turbulent flow, developed by Prandtl [7] and [8], is used in this approach. Further derivation and detailed explanations of previous equation are presented in the paper [2].

The numerical model is developed in Fluent (AnsysFluid Dynamic) program surrounding, which uses the finite volume method. The computation domain consists of 1.330.724 hexagonal elements. The tracking of the interfaces between the components is accomplished by the solution of a continuity equation for the volume fraction of one or more of the components [6]. The computational grid is denser in the bend region and downstream of it, and in the vicinity of the contour. The water level and the mass flow rate of water and air were prescribed at the upstream end of the conduit, while the free outflow is imposed at the downstream end.

Comparison of the results obtained by the scale and numerical models, for helicoidal flow without choking, and deflection angle of $45^{\circ}$ and curvature $D / R=1 / 3$, is presented at Fig. 8. Helicoidal flow occurred for the water flow of $22,4 \mathrm{l} / \mathrm{s}$ and approach flow depth of $9,1 \mathrm{~cm}$.

One can observe a good agreement between the observed (scale model) and computed (numerical model) flow field.

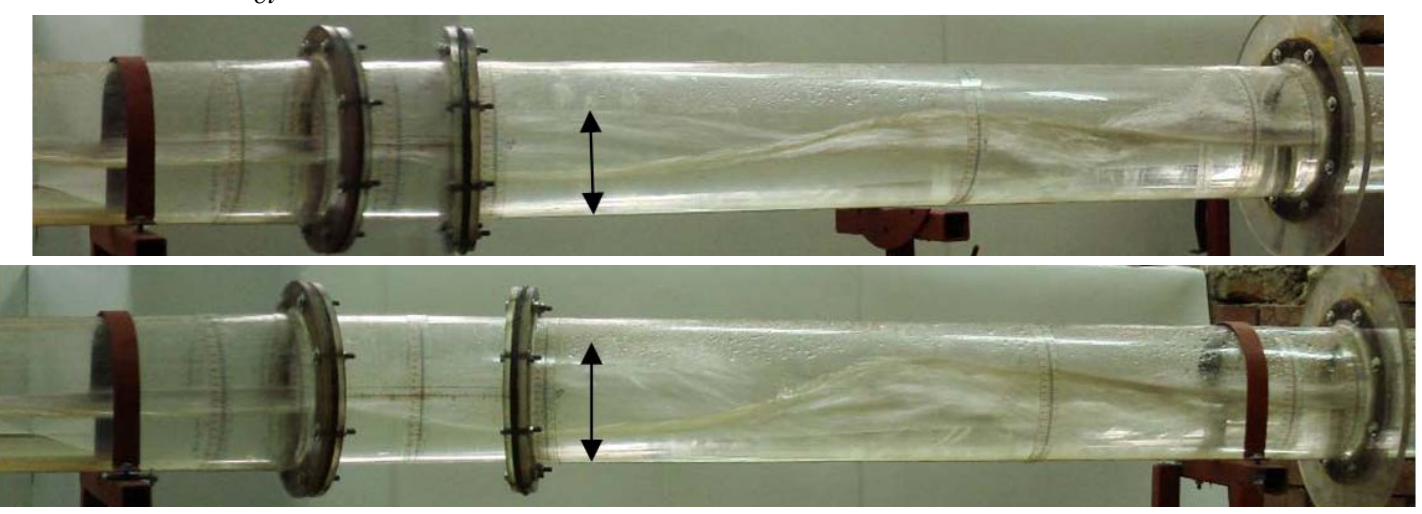

a) $\alpha=15^{\circ}$

b) $\alpha=30^{\circ}$

Figure 6. Flow without jet turning for $15^{\circ}$ and $30^{\circ}(D / R=1 / 3)$

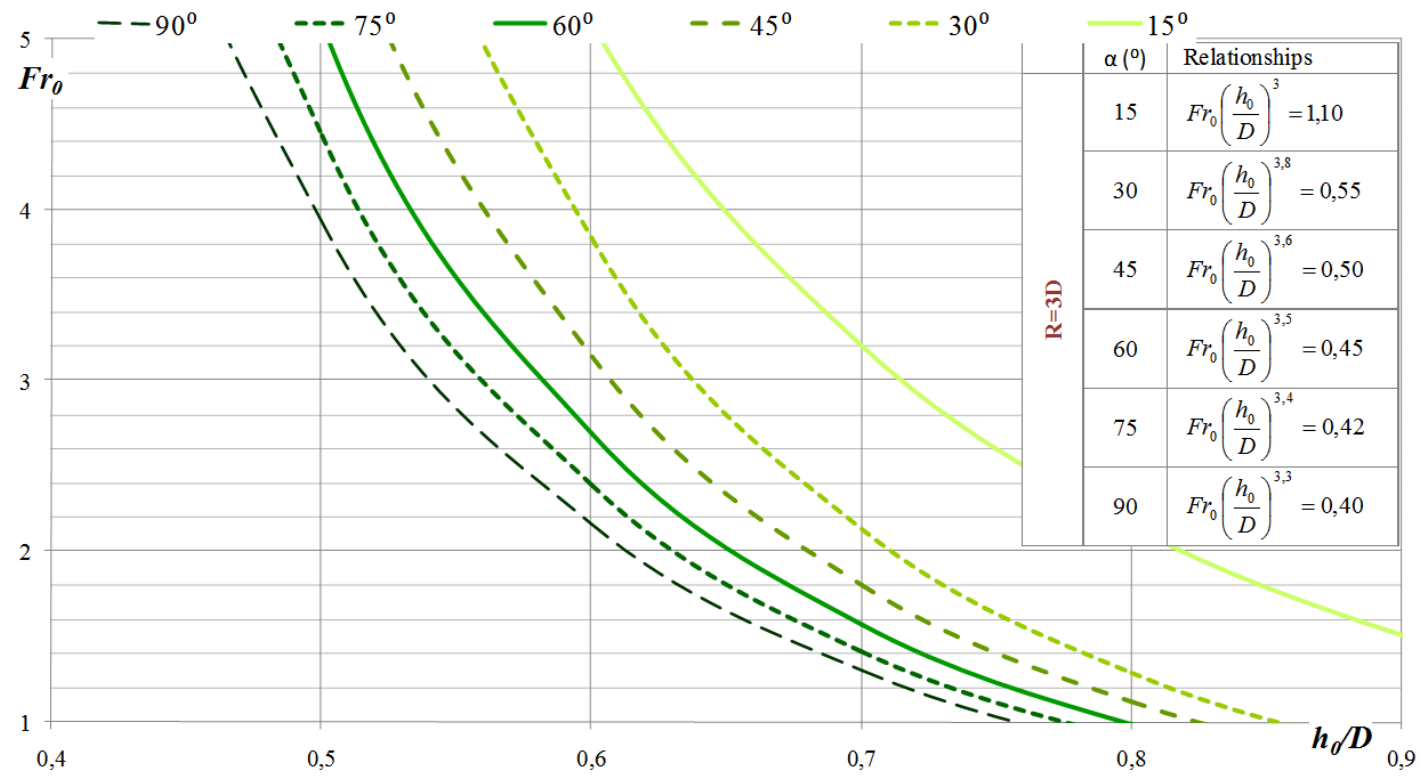

Figure 7. Limits of choking for considered deflection angles and $D / R=1 / 3$ 


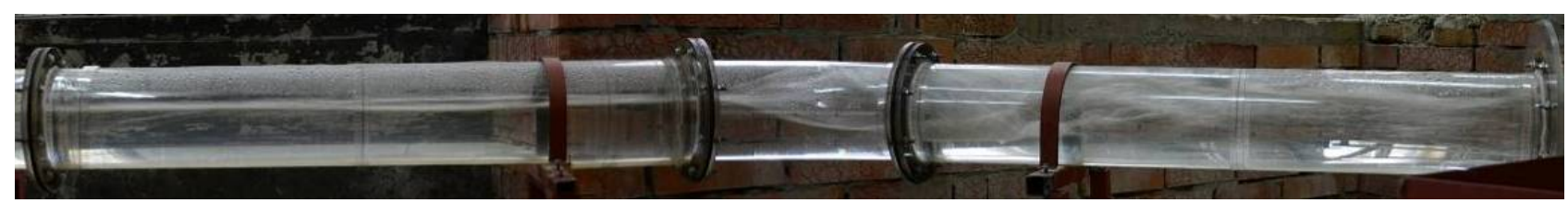

a) The hydraulic scale model

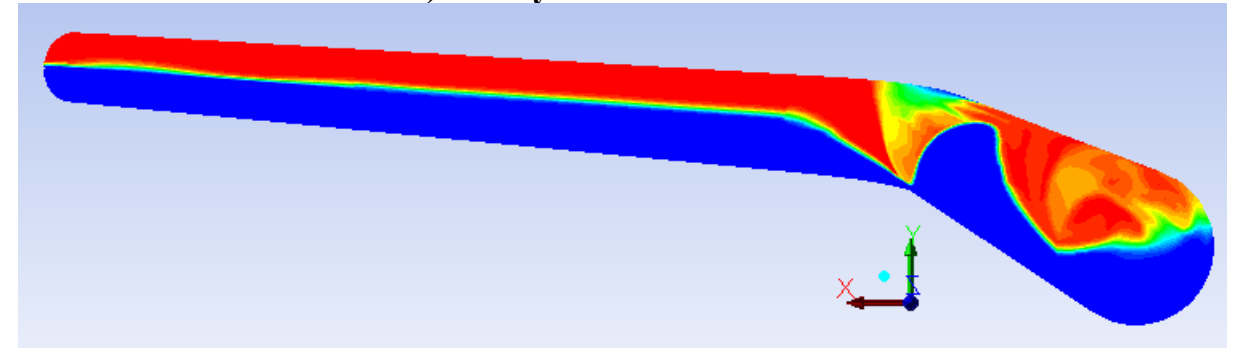

b) Numerical model

Figure 8. Comparison of hydraulic scale model and numerical model: Helicoidal flow in the conduit

\section{CONCLUSIONS}

Based on the hydraulic scale model experiments, empirical relationships for threshold of helicoidal and choking flow in a circular conduit bend with free surface flow, were developed. The relationships are given as functions of non dimensional approach depth, $h_{0} / D$, and approach Froude number, for considered deflection angles and bend curvature of $D / R=1 / 3$.

A comparison of the results obtained by the scale and the numerical model, showed satisfactory agreement.

The effect of the bend curvature will be the topic of a following study.

\section{ACKNOWLEDGMENT}

This work was supported by the Ministry of Education and Science of the Republic of Serbia under project no. TR 37009 "Monitoring and Modeling of Rivers and Reservoirs - Physical, Chemical, Biological and Morphodynamic Parameters", and project no. TR 35043 .

\section{REFERENCES}

[1] Gisonni, C. and Hager, W. H.: Bend flow in bottom outlets, from the Internet, 2000.

[2] Mladenović, N., Mitrović, Z. and Rusov, S.: Numerical Flow Computation in Presence of Multicomponent Fluid Injection, in: Proceeding of the Second International Congress of Serbian Society of Mechanics, 01-05.06.2009, Palić, Paper A-01:1-15.

[3] Hirsch, C.: Numerical Computation of Internal and External Flows, John Wiley and Sons, Chichester, 1992.

[4] Randall, J.L.: Finite Volume Methods for Hyperbolic Problems, Cambridge University Press, Cambridge, 2003.

[5] Versteeg, H.K. and Malalasekera, W.: An Introduction to Computational Fluid Dynamics - the Finite Volume Method, Pearson Education Limited, Harlow, 2007.

[6] FLUENT INC.: Fluent Reference Manual, FLUENT Corporation, New York, 1999.

[7] Shetz, J.A.: Boundary Layer Analysis, Prentice Hall, Englewood Cliffs, 1993.

[8] Patankar, S.V. and Spalding D.B.: Heat and Mass Transfer in Boundary Layers, Intertext Books, London, 1970.

[9] Hutli, E.A.F. and Nedeljković, M.: Investigation of a Submerged Cavitating Jet Behaviour: Part One The Phenomenon, Detection Technique and SonoLuminesence, FME Transactions, Vol. 35, No. 3, pp. 113-119, 2007.

[10] Hutli, E.A.F. and Nedeljković, M.: Investigation of a Submerged Cavitating Jet Behaviour: Part Two Influences of Operating Conditions, Geometrical Parameters and Arrangements of Detection System, FME Transactions, Vol. 35, No. 3, pp. 121-128, 2007.

\section{БУРНО ТЕЧЕЊЕ У КРИВИНИ КРУЖНЕ ЦЕВИ}

\section{Милена Коларевић, Љубодраг Савић, Радомир Капор, Никола Младеновић}

У раду је анализирано сложено струјање које настаје у кривини затвореног проводника у бурном току. Испитивања су урађена на хидрауличком физичком моделу, али и на нумеричком, формираном у оквиру програмског пакета Ansys (Fluent). Резултати са хидрауличког модела су коришћени за калибрацију нумеричког, па је у оквиру рада приказано поређење резултата добијених на поменута два модела, са коментарима и препорукама за њихову примену. На основу извршених испитивања дате су једноставне зависности којима се описује утицај величине скретног угла и прилазних услова течења (дубина и Фрудов број узводно од кривине) на разматрано течење. 